\title{
Female figures in Maritime Education and Training Institutions between 2009 and 2018: analysing possible impacts of gender policies
}

\author{
CLÀUDIA BARAHONA-FUENTES \\ Corresponding author \\ Department of History and Theory of Architecture and Communication Techniques. \\ Barcelona School of Nautical Studies (FNB). Universitat Politècnica de Catalunya - BarcelonaTech \\ Pla de Palau, 18, 08003 Barcelona, Spain \\ e-mail: claudia.barahona@fnb.upc.edu, +34 934017919 \\ Orcid: 0000-0001-8599-8188
}

MARCELLA CASTELLS-SANABRA

Department of Nautical Science and Engineering.

Barcelona School of Nautical Studies (FNB). Universitat Politècnica de Catalunya - BarcelonaTech

Orcid: 0000-0002-9038-3126

\section{SANTIAGO ORDÁS}

Department of Nautical Science and Engineering.

Barcelona School of Nautical Studies (FNB). Universitat Politècnica de Catalunya - BarcelonaTech

Orcid: 0000-0002-8585-9361

\section{JORDI TORRALBO}

Department of Nautical Science and Engineering.

Barcelona School of Nautical Studies (FNB). Universitat Politècnica de Catalunya - BarcelonaTech

Orcid: 0000-0002-9718-4699

\section{ACKNOWLEDGMENTS}

We greatly acknowledge the Higher Education Schools of Maritime Studies (HZS, US_FMS, SAMK, UCG, HVL, GMU, SMU-P, CMU, UNILI, SMT-CUT, UNIOVI, UPV/EHU, UPC-FNB, ASST-MT, UTP, ENU, UMIP) and the Spanish Maritime Administration (DGMM) for their support throughout this MET gender study. 


\title{
Keywords.
}

Maritime education and training (MET), female students, women promotion policies, gender equality, role of women in the maritime sector, women professional career

\begin{abstract}
.
This paper intends to provide a figure analysis of female students in Maritime Education and Training (MET) institutions over a decade (2009-2018) with the aim to analyse the possible impact of the gender equality policies applied. In recent years, while there has been an increase of female students in many technical degrees, in maritime education the gender imbalance seems to persist. This study of female student enrolment and graduation figures of some MET institutions provides a picture of current trends in the maritime education sector. The results are not very encouraging as they reveal an unchanging tendency concerning gender equality in this field of studies. In addition, the analysis of gender policies unveils that there is still a lot of work to be done. Such policies are scarce or inexistent and do not have a significant effect towards reducing this gender gap. In order to identify possible parallelisms in the professional sector, we also analysed the percentages of women in deck and engine positions issued by the Spanish Maritime Administration during the period studied. The case of Spain shows that this gender inequality is even more profound in the maritime professional sector. The study concludes that in spite of an increasing awareness the gender gap continues both in the educational and professional sector. Hence, the joint involvement of national maritime administrations and international maritime organisations and agencies is needed to develop more effective gender equality policies and programmes for a more egalitarian and inclusive maritime training and professional sector.
\end{abstract}




\title{
Keywords
}

Maritime education and training (MET), female students, women promotion policies, gender equality, role of women in the maritime sector, women professional career

\begin{abstract}
This paper intends to provide a figure analysis of female students in Maritime Education and Training (MET) institutions over a decade (2009-2018) with the aim to analyse the possible impact of the gender equality policies applied. In recent years, while there has been an increase of female students in many technical degrees, in maritime education the gender imbalance seems to persist. This study of female student enrolment and graduation figures of some MET institutions provides a picture of current trends in the maritime education sector. The results are not very encouraging as they reveal an unchanging tendency concerning gender equality in this field of studies. In addition, the analysis of gender policies unveils that there is still a lot of work to be done. Such policies are scarce or inexistent and do not have a significant effect towards reducing this gender gap. In order to identify possible parallelisms in the professional sector, we also analysed the percentages of women in deck and engine positions issued by the Spanish Maritime Administration during the period studied. The case of Spain shows that this gender inequality is even more profound in the maritime professional sector. The study concludes that in spite of an increasing awareness the gender gap continues both in the educational and professional sector. Hence, the joint involvement of national maritime administrations and international maritime organisations and agencies is needed to develop more effective gender equality policies and programmes for a more egalitarian and inclusive maritime training and professional sector.
\end{abstract}

\section{INTRODUCTION}

The limited number of female students enrolled in Marine Engineering and Maritime Navigation studies and the lack of gender-policies in most MET institutions is becoming an increasing cause of concern in the maritime education sector. Research in the field suggests that this is a widespread problem across countries, which requires immediate attention from the corresponding agents (UPC 2007; De la Campa et al. 2013; Romero and Kitada 2013). The proportion of women earning technical degrees has increased steadily during the last decades. However, technical professions, including those in the maritime sector, show a clear gender gap with respect to jobs and managerial positions, namely, both in their horizontal and vertical dimensions (De la Campa et al. 2013; Boström and Österman 2015). This gender inequity has its roots at university level where male students clearly outnumber female ones, so a better understanding of the current situation may be key to provide a new insight into this problem so that we can find ways to reverse the present numerical inequality and resolve existing gender bias in the future.

Up to the present, several attempts have been made at promoting the incorporation of female students in higher education both at institutional and international level. For example, at international level we find IMO's programme on the Integration of Women in the Maritime Sector (IWMS) whose primary objective is "to encourage IMO Member States to open the doors of their maritime institutes to enable women to train alongside men and so acquire the high-level of competence that the maritime industry demands" (IMO 1989). However, most of the times, such programs are addressed to women in developing countries where they have even more difficulties for enrolling in maritime programs. At institutional level, the incorporation of more inclusive gender policies is most of the times dependent on institutional leaders and their awareness and goodwill to address these issues (UPC 2016) or on individual initiatives. Therefore, although some policies for gender equity have already borne their fruits, we are still far from the intended equity expectations. In addition, increasing numbers of female students is not enough because as some authors point out "without effective gender-inclusive strategies and pedagogical and didactic approaches, there is a risk of reproducing inequality instead of producing equality" (Boström and Österman 2015). Hence, promotion policies for incorporating more female students in maritime training is only the first step, and should go hand in hand with specially-designed curricula integrating gender issues.

These inequities at training level are reproduced in the professional sector where women are clearly underrepresented at all levels. On the one hand, this can be due to the lack of specific policies or regulations with respect to women recruitment and working conditions (YaleGlobal 2003). On the other hand, the history and legacy of an almost entirely male profession also constitutes a major drawback for the employment of women at sea or ashore and for the construction of a female professional identity (Walker et al. 2003). In response to 
this, different groups and associations have begun to emerge to support women in this sector such as WISTA, a Women's International Shipping and Trading Association, which attracts and promotes women, at the management level, in the maritime, trading and logistics sectors. In line with this, for the World Maritime Day 2019, IMO chose the theme "Empowering Women in the Maritime Community", which provides an opportunity to raise awareness of the importance of gender equality and to highlight the important and necessary contribution of women in the maritime sector.

In the following sections, this article discusses some educational and professional policy issues on gender equality in the maritime sector. It also presents the methodology and results of a small-scale study concerning the figures of female student enrolment and graduation in some MET institutions over the last decade. Finally, the article ends up with some conclusions drawn from the findings and observations of this research.

\section{POLICY ISSUES ON GENDER EQUALITY IN THE MARITIME EDUCATIONAL AND PROFESSIONAL SECTOR}

Recent figures from the International Transport Workers' Federation (ITF) show that women currently make up only a $2 \%$ of the global maritime workforce and that the majority of them are employed on cruise ships or passenger ferries (Ship Technology 2018). Nevertheless, it has been demonstrated that countries with more gender equality have better economic growth and that companies with more women leaders perform better (Joy, Wagner and Narayanan 2007). Therefore, it is clear that equality for women means progress and benefits us all. In response to this, different initiatives have emerged to foster the role of women in the maritime sector. For example, in 1988, IMO launched its Women in Maritime gender programme, under the slogan: "TrainingVisibility-Recognition", which enhances the contribution of women as key maritime stakeholders and supports their participation in both shore-based and sea-going posts (IMO 1988). This programme was initiated when the majority of MET institutions were still exclusively for male students but, with the help of this programme, which incorporated a gender dimension into IMO's policies and procedures, the access and opportunities for women in the maritime sector have been favoured and supported, thus contributing to an increase of the still low figures of women in maritime training and employment. IMO also supports the access to high-level technical training for women in the maritime sector, particularly in developing countries, through gender specific fellowships. This favours gender equality, the empowerment of women and the creation of new career development opportunities for them in countries where their contribution is specially under-utilized. In addition to this, through its gender and capacity-building programme, IMO has also supported the creation of seven regional associations for women in the maritime sector, namely, Women in Maritime Associations (WIMAs). These regional networks cover Africa, Asia, the Caribbean, Latin America, the Middle East and the Pacific Islands and access to them has provided their members with a much-needed platform to discuss gender issues. On the other hand, the ITF is also strongly engaged in the gender dimension of transport as they believe that addressing this issue will benefit not only women but all transport users. At present, only $22 \%$ of transport employees in the European Union are female, this goes down to $20 \%$ in the Asia-Pacific region and drops to $14 \%$ in the United States (ITF 2019). Hence, to cope with shortages of qualified professionals, the transport sector (including the maritime one) will need to incorporate a gender perspective in order to attract, train and recruit women at all levels.

The role of higher education institutions is key in addressing gender equality issues in maritime instruction. According to Cars and Österman (2015), MET is crucial in molding future seafarers who are gender and culturesensitive and MET institutions are important bearers of societal norms and values. A recent research project, Gender Equality and Cultural Awareness in Maritime Education and Training Project (Dragomir et al. 2018), examines various leadership and coaching techniques practiced by maritime education and training institutions in promoting gender equality and cultural awareness. Another research study carried out in 2015 (Horck 2010) examined how gender equality was addressed in the curricula of maritime education, examining official study plans and curricula from eight maritime universities in Finland, Norway, Sweden and the Philippines; all countries ranked in the top five in the Global gender Gap Index. However, the main conclusion drawn was that gender issues are not a visibly integrated part of curricula in any of the eight universities studied. In keeping with this need of integrating gender issues in higher education, the Swedish World Maritime University (WMU), a postgraduate maritime university founded by the International Maritime Organization, has developed and implemented its own policies to achieve gender equality and women's empowerment in the maritime transport sector as reported by several authors and reflected in the University Strategic Plans (Horck 2010; Romero and Kitada 2014). A case study developed in 2017 (Romero 2017) looked at how WMU's policies on gender equality and women's empowerment have evolved over time and analysed their impact on students and 
employees, curriculum, conferences and seminars with a view to propose areas for improvement. From this case study, several conclusions were drawn: Policies adopted for increasing the number of female graduates have been relatively successful as an augmented presence in the student body has been recorded; the policies adopted for reaching gender parity within the faculty have opened the doors for female academics to join the University, which in turn benefits the maritime sector by incorporating the female perspective in education and, finally, the gender perspective has been integrated in sections of the curriculum, conferences and seminars. However, efforts in this direction must be continued and improved if we want to obtain effective outcomes in the long run.

In Europe, education policy issues on gender equality are considered since the applicability of the new European Higher Education Area (EHEA), which was launched in 2010 along with the Bologna Process' decade anniversary. Top-level legislation offers support to Higher Education Institutions (HEIs) promoting gender equality in more than half of the EHEA educational systems ${ }^{1}$ (European Commission 2018), as shown in Fig. 1. For a quarter of the educational systems, there is specific higher education legislation supporting institutions in the promotion of these societal goals and values and for the other quarter, decisions on the promotion of gender equality are left to higher education institutions themselves. The most common requirements listed in such legislation regarding the promotion of gender equality, political and religious tolerance, and democratic and civic values are anti-discrimination measures concerning the appointment and promotion of staff, and equal access to education and learning.
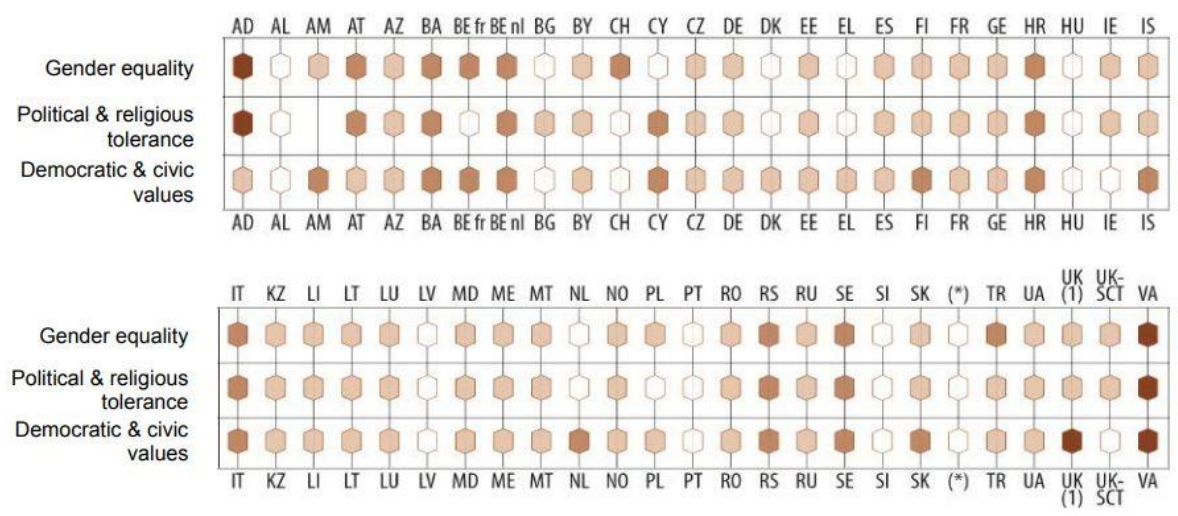

$\left(^{\star}\right)$ : the former Yugoslav Republic of Macedonia; UK (1): UK-ENG/WLS/NIR

Top level legislation $\quad$ Specific HE legislation

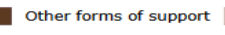

HEIs decide on their own

Fig. 1 Support for higher education institutions to promote gender equality, political and religious tolerance, and democratic and civic values, 2017 (European Commission 2018)

On the other hand, gender equality is also a key priority of the Member States and Associated countries in the European Research Area. Horizon 2020, the biggest EU Research and Innovation programme ever with nearly $€ 80$ billion of funding available over seven years (2014 to 2020) includes gender as a cross-cutting issue in each of the different parts of its Work Programme, thus ensuring a more integrated approach to research and innovation (European Commission 2019). The three main objectives that underpin the strategy on gender equality are: fostering gender balance in research teams, ensuring gender balance in decision-making and integrating the gender dimension in research and innovation (R\&I) content. One of its specific work programmes, Science with and for Society, funds specific initiatives in support of the gender equality strategy to remove barriers that generate discrimination against women in scientific careers, and to integrate a gender dimension in research and innovation content. In addition, the programme funds the development of a common framework to assess national initiatives promoting gender equality in research policy and promotes campaigns encouraging girls to study science and female students to do research. All these activities are targeted to researchers and innovators, research organisations, primary, secondary and higher education establishments,

\footnotetext{
${ }^{1}$ The EHEA / BFUG members are 48 countries and the European Commission. However, a member country may have more than one educational system. For example, the Flemish and French Communities of Belgium are considered as distinct higher education systems.
} 
science museums, citizens and their associations or groupings, media, policy makers at national, regional and local levels, etc. From the maritime point of view, an example of a EU programme addressing gender equality is "Blue Careers" under the European Maritime and Fisheries Fund (EMFF). One of the objectives considered in the projects submitted is whether they address the gender imbalance in the blue economy and encourage women to step into traditionally male-dominated work areas and vice-versa.

At national level, different laws on effective equality between women and men have also been passed. For example, in Spain, there are some laws (BOE 2007; DOGC 2015) that promote equal treatment and opportunities for women and men in employment by which public authorities are supported to improve the employability and employment of women regarding access to work, presence and permanence in work and working conditions. To this end, public authorities shall take measures to increase the percentage of women in sectors, occupations or professions in which they are poorly represented. In addition, they shall promote greater professional diversification of women in the labour market and eliminate horizontal segregation, adopting the necessary measures to facilitate not only the incorporation of women in sectors of the economy that are traditionally masculinized but also that of men in traditionally feminized sectors, while ensuring that the feminized sectors are revalued socially and have the same recognition and the same working conditions as the others. These regulations and guidelines are also extended to the educational sector.

The study presented in this paper aims to determine the outcomes of all these gender equality policies and legislation on maritime education, which at the same time will have a direct impact on the maritime professional sector. An analysis of the enrolment and graduation figures of female students in several MET institutions over the last decade (2009-2018) was conducted with the aim of examining the effect of such policies and so provide a better understanding of the current situation in MET institutions. To this end, the female student promotion and gender policies applied in the different HEIs analysed over the same period of time were also considered to determine their effectiveness on female student enrolment.

\section{METHODOLOGY}

This paper describes a small-scale study concerning the figures of female student enrolment and graduation in some MET institutions and their evolution over the last decade (2009-2018). The participating centres are all Higher Education Schools of Maritime Studies, namely, thirteen schools in ten different European countries, two in South America and one in Africa (see Table 1). The last three institutions were included within a group of non-European countries. This way, European countries and non-European countries were analysed separately. The group of European universities comprises three schools in Spain, which were also considered independently in this research to contrast Spanish and European outcomes. Ten of these sixteen institutions belong to the International Association of Maritime Universities ${ }^{2}$ (IAMU), which is a global network of leading maritime universities providing MET of seafarers for the global shipping industry. All of them were chosen for their commitment to MET and because they constitute a fairly representative sample of the European area.

With the collaboration of all the MET centres participating in the study, we gathered data corresponding to access and graduate figures of female students since 2009 , which were examined in order to discover any trend or general pattern of evolution. With the aim of providing some tentative explanation on the findings, we also requested information concerning the implementation of institutional policies aiming at gender equality and university groups promoting those policies in the mentioned institutions.

\begin{tabular}{|l|l|l|}
\hline Country & Institution & Identifying acronym \\
\hline European countries & HZS \\
\hline Belgium & Antwerp Maritime Academy & US_FMS \\
\hline Croatia & University of Split, Faculty of Maritime Studies* & SAMK \\
\hline Finland & Satakunta University of Applied Sciences* & UCG \\
\hline $\begin{array}{l}\text { Montene } \\
\text { gro }\end{array}$ & University of Montenegro & HVL \\
\hline Norway & Western Norway University of Applied Sciences* & GMU \\
\hline Poland & Gdynia Maritime University* & SMU-P \\
\hline Poland & Szczecin Maritime University* & CMU \\
\hline Romania & Constanta Maritime University* & UNILJ \\
\hline Slovenia & University of Ljubljana & \\
\hline
\end{tabular}

\footnotetext{
${ }^{2}$ Those universities in Table 1 that have an asterisk (*) are IAMU members.
} 


\begin{tabular}{|l|l|l|}
\hline Sweden & Chalmers University of Technology* & SMT-CUT \\
\hline \multicolumn{2}{|l|}{} \\
\hline Spain & Universidad de Oviedo, Escuela Superior de la Marina Civil & UNIOVI \\
\hline Spain & Universidad del País Vasco, Escuela de Ingeniería de Bilbao & UPV/EHU \\
\hline Spain & Universitat Politècnica de Catalunya, Facultat de Nàutica de Barcelona* & UPC-FNB \\
\hline Non-European countries & AAST-MT \\
\hline Egypt & Arab Academy for Science, Technology and Maritime Transport* & UTP \\
\hline Perú & Universidad Tecnológica de Perú* & ENU \\
\hline Uruguay & Escuela Naval de Uruguay &
\end{tabular}

Table 1 Participating institutions

All the participating institutions were sent a form they completed with the total number of students and the number of female students enrolled and graduated since 2009. The same form included some space for describing the female student promotion policies applied in their schools during those years. With the data gathered, the percentages of female students enrolled and graduated each year was calculated for each university and plotted on a graph to determine any possible similarities and differences. Then, the mean value of all the percentages from the different institutions for each academic year was calculated to observe any possible global trend. Here, we considered European universities, including also the results from Spanish schools, and then compared the European global trend to the Spanish one. The mean values for these two groups were also plotted on graphs to detect any tendency over the last decade.

In the case of Spain, this study also covers the situation of women working at sea over the same period of time. For this purpose, data concerning the number of women that joined the professional sector as seafarers was also requested to the Spanish Merchant Marine Administration. The figures of women that became Deck Officers, Engineering Officers, Captains and Chief Engineers were compared to the global ones and were also plotted on graphs to provide an interpretation.

\section{RESULTS AND DISCUSSION}

The results of this small-scale study are grouped into three main areas; namely, evolution of access and graduation figures of female students of all the universities analysed, effects of the institutional policies for engaging female students and trends concerning figures of women engaged in professional careers at sea in Spain over the last decade.

\subsection{Access and graduation figures of female students in MET institutions}

The access and graduate figures for female students in all the universities analysed show that there is still a small percentage of them that begin and complete their training in MET institutions during the period evaluated and that the situation does not improve over time. In the graphs on enrolment figures, it can be noted that the number of women that begin Nautical Science and Maritime Transport Studies is considerably higher than that of women beginning Marine Engineering Studies in all universities except for the Universidad Tecnológica del Perú and Arab Academy for Science, Technology and Maritime Transport (see Fig.2).

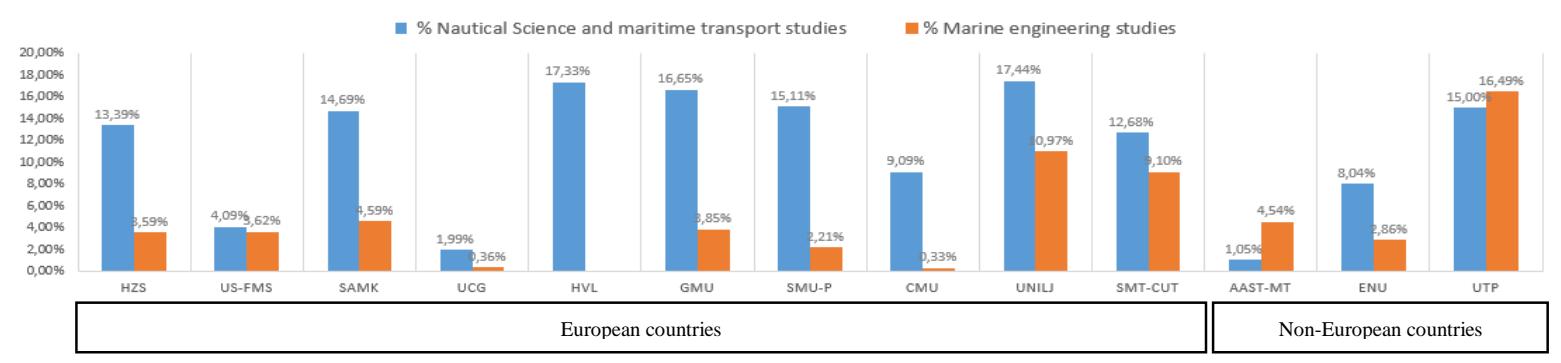

Fig. 2 European and Non-European countries - Average of enrolled 1st year female students (2009-2017)

If we consider these enrolment figures over time, that is, the mean enrolment values of all European 
universities for each academic year, a similar trend can be observed ${ }^{3}$ (see Fig. 3). It is noteworthy that, contrarily to our expectations, an upward trend cannot be appreciated over that period. The mean values for all the European institutions, including Spain, show that the access figures of female students in Nautical Science and Maritime Transport Studies is $13.50 \%$ whereas in Marine Engineering Studies decreases to $6.25 \%$.

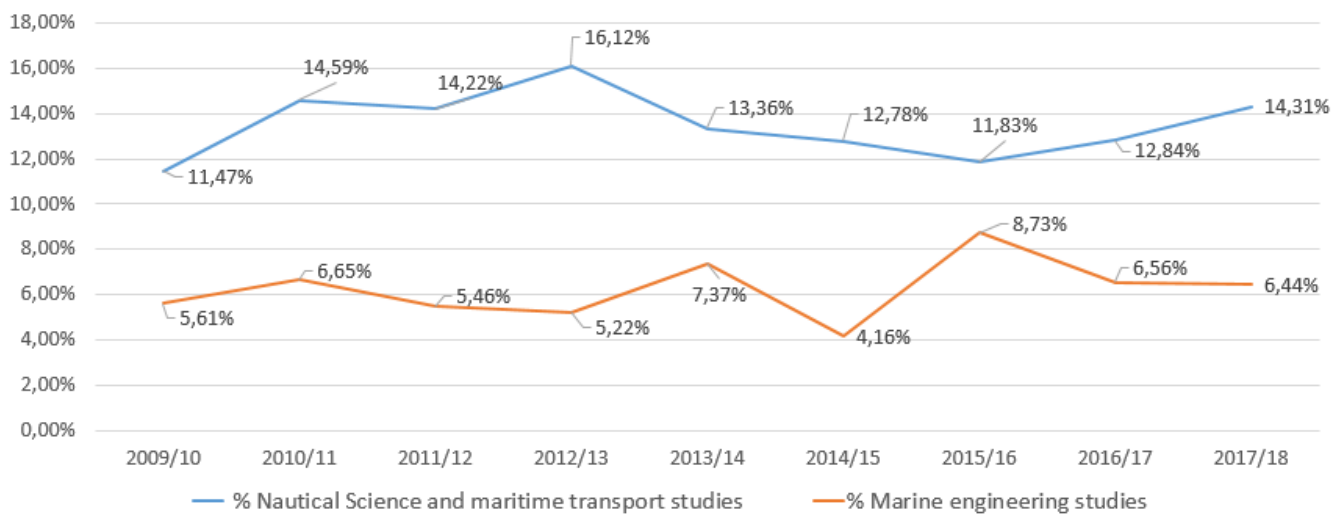

Fig. 3 European countries - Average of enrolled 1st year female students (2009-2017)

With respect to the figures of graduated female students, the results display a similar tendency (see Figure 4). The mean values of graduated female students from all European institutions distributed over academic years, in the same way as with access figures, reflect no gradual increase, only some occasional rise (see Fig. 5). Over this ten-year period, the mean value of graduated female students in Nautical Science and Maritime Transport Studies is $15.88 \%$ whereas in Marine Engineering Studies is 5.92\%. As can be noted, the graduation figures for Nautical studies are slightly higher than those for enrolment whereas in Marine Engineering figures stayed level. Since these percentages are calculated over the total number of students enrolled and graduated, a possible interpretation could be that fewer girls than boys abandon their studies in Nautical science and Maritime Transport.

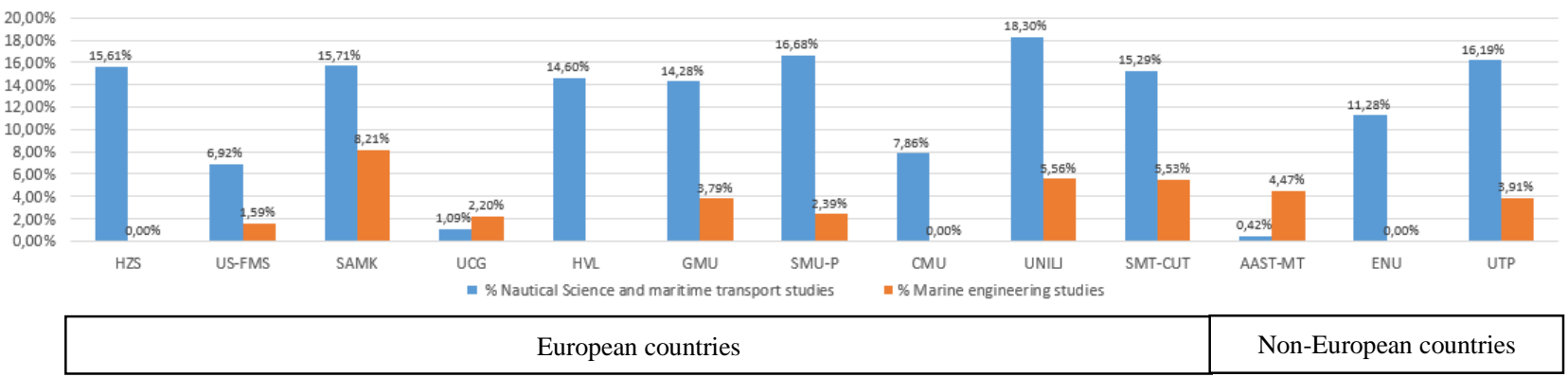

Fig. 4 European and Non-European countries - Average of graduated female students (2009-2017)

\footnotetext{
${ }^{3}$ In the graphs that show the development of figures over time, only European Universities, including Spanish universities, were surveyed. Non-European universities were not considered for this analysis as three institutions do not constitute a representative sample.
} 


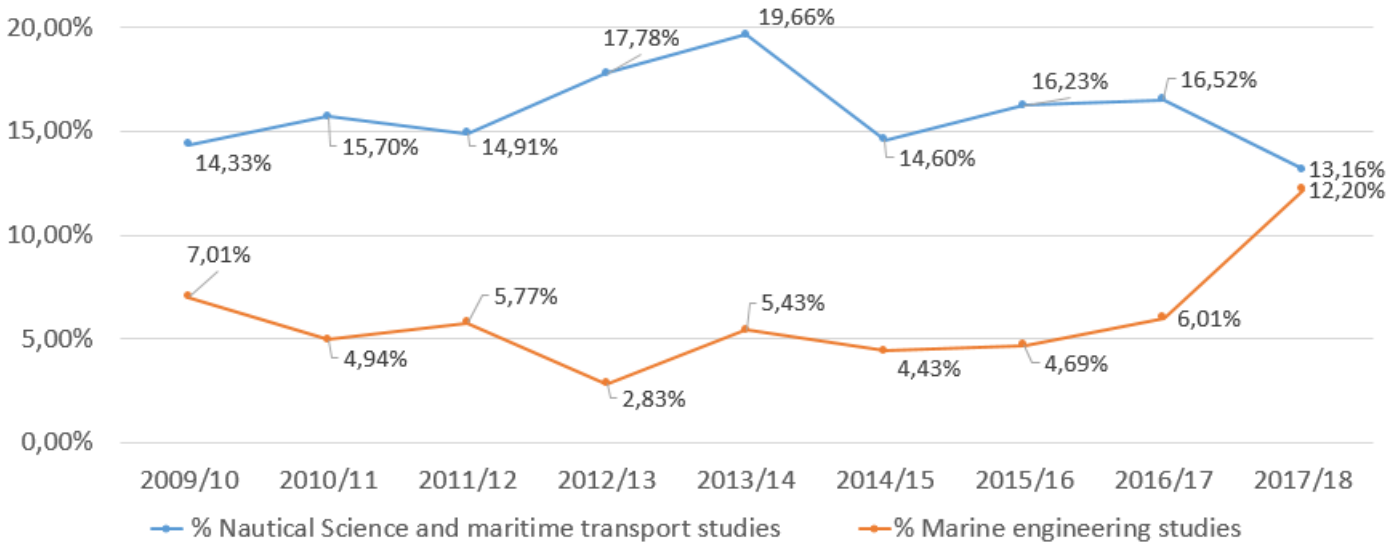

Fig. 5 European countries - Average of graduated female students (2009-2017)

Considering Spain separately, with respect to the three schools examined, it can be seen that, on average, there is a higher percentage of girls in these studies in Spain than in the rest of European countries (see Fig. 6).

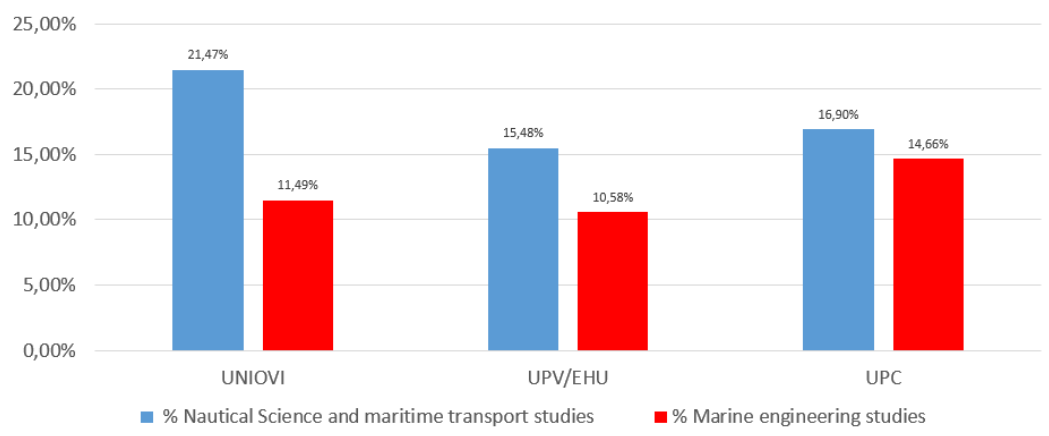

Fig. 6 Spain - Average of enrolled 1st year female students (2009-2017)

Analysing enrolled female students over the last decade, the tendency in Spain is the same as that observed for European countries (see Fig. 7). Here again there is no significant increase over this period. The mean access value of female students in Nautical Science and Maritime Transport Studies is $17.95 \%$ and $12.24 \%$ for Marine Engineering Studies. In line with this, the figures of graduated female students in Spain follow the same pattern (see Fig. 8 and 9). For graduated Nautical Science and Maritime Transport female students the mean value is $27.47 \%$ and for graduated Marine Engineering female students is $11.20 \%$ over this last decade. In the case of Spain, the only significant difference as compared to the mean values of European countries is that although there is also an increase on the graduated figures for Nautical Science and Maritime Transport studies, with respect to access figures, Marine Engineering studies show a reverse tendency, which means that more girls than boys abandon these latter studies. 


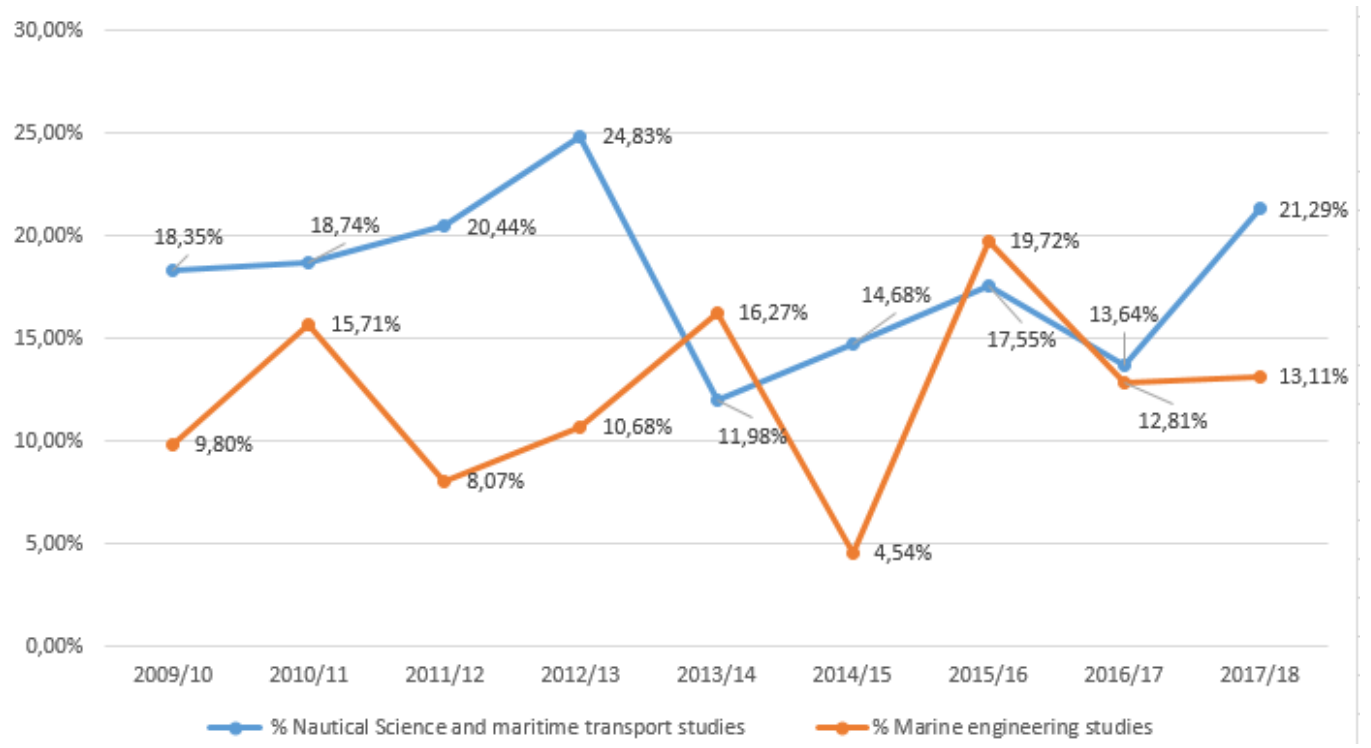

Fig. 7 Spain - Average of enrolled 1st year female students (2009-2017)

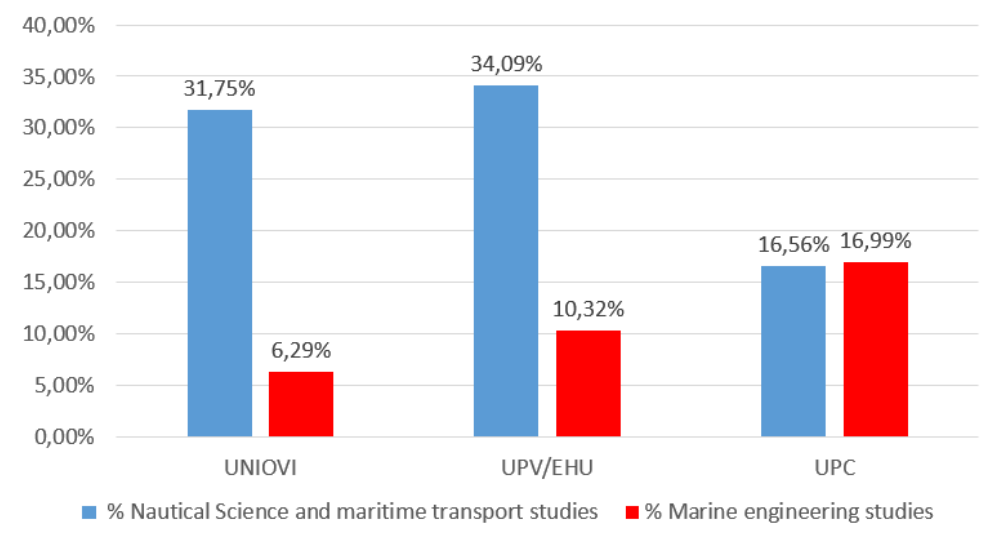

Fig. 8 Spain - Average of graduated female students (2009-2017) 


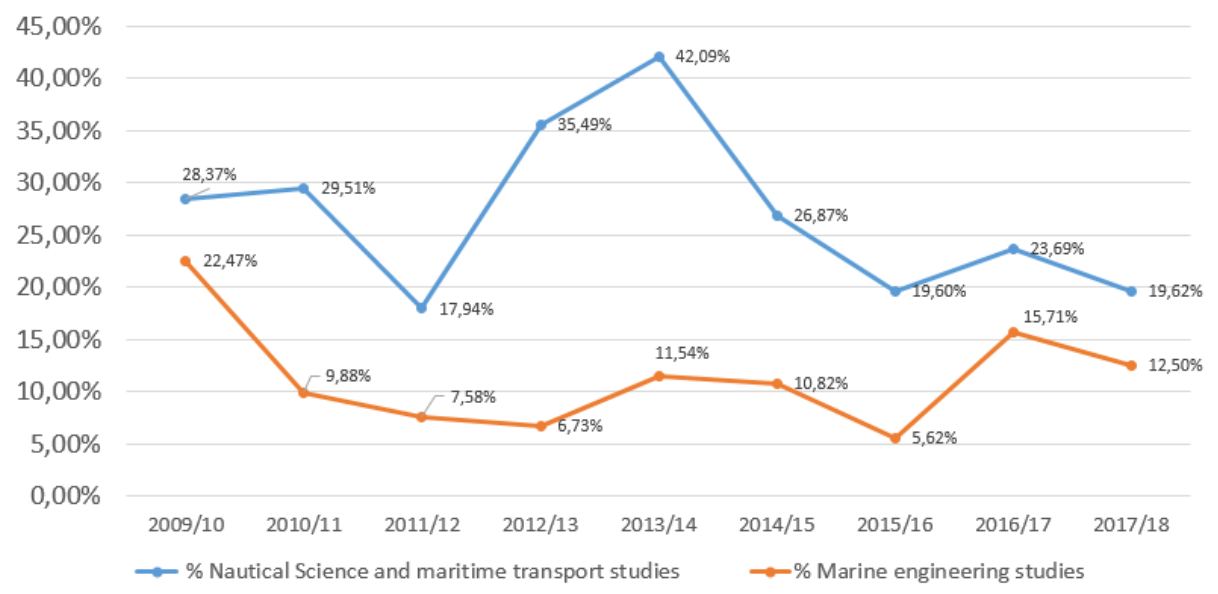

Fig. 9 Spain - Average of graduated female students (2009-2017)

\subsection{Institutional policies for engaging female students}

In the majority of countries analysed, no promotion policy for female students in Maritime studies was implemented over the period studied except for Szczecin Maritime University and Universitat Politècnica de Catalunya (UPC). Szczecin Maritime University obtained two promotion projects financed by the EU during 2011-2013 and part of the budget had to be obligatorily addressed to women. As a result, there was a general increase in admissions and also in the number of female students admitted those years. Universitat Politècnica de Catalunya also launched the I Equal Opportunities Master Plan in 2007 with the general aim of promoting a culture of equity and equality of opportunities for women. Among some more specific objectives, there was promoting a balance between men and women in the different UPC engineering studies. The I Plan lasted for two years and then during the period between 2013-2015, the II Plan was implemented (UPC 2013). Since 2016, the III Plan for Gender Equality is in place. In this occasion, these plans are not particularly addressed to Maritime studies, but to engineering studies in general. However, Facultat de Nàutica de Barcelona also benefited from all these promotion policies and slightly increased the number of female students enrolled when the plan was launched (Martínez de Osés 2002). At institutional level, namely, considering all the different UPC Schools, the report on the implementation results of the II Plan shows a slight increase in female student enrolment at degree level and a stabilisation of the falling tendency at master and doctoral level. These results are not very encouraging and demand more work on gender equality to be carried out. As for the other participating institutions, there is no information on any specific female student promotion policy over the period analysed. Hence, the average increase and decrease in 1st year female student enrollment must be due to other circumstances such as demographic factors or general promotion university policies. The limitations of this study did not consider any additional aspect that could influence the results. Therefore, some more research is needed out to determine the changing nature of trends.

\subsection{Women engaged in professional careers at sea in Spain}

In 1960, Spain had a legal provision impeding women from joining the Spanish Armed Forces which extended to Merchant Marine Schools. Such a disposition was not repealed until the 80s, after the approval of the 1978 Constitution, which introduced the principle of equality of men and women before the law without distinction as to sex. Thus, during the academic year 1979-80, women could enroll for the first time in Merchant Marine studies in Spain. Some years after, in 1984 the first woman became Second Deck Officer. In line with this, in 2012 the first woman was appointed Harbour Master (at present there are two women in such a position) and in 2015 the first woman became pilot, and she is still the only one up to the present. From this it follows that women still have a long way to go in the maritime professional sector in Spain. 


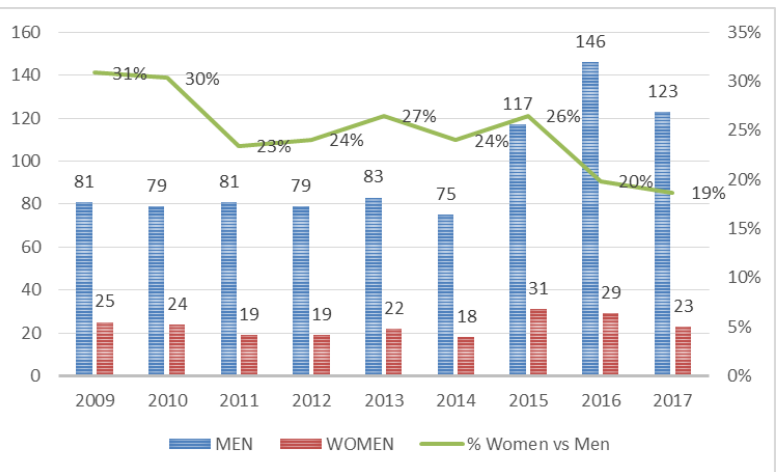

Fig. 10 Master CoC Gender Distribution

Fig. 11 OOW Navigation CoC Gender Distribution
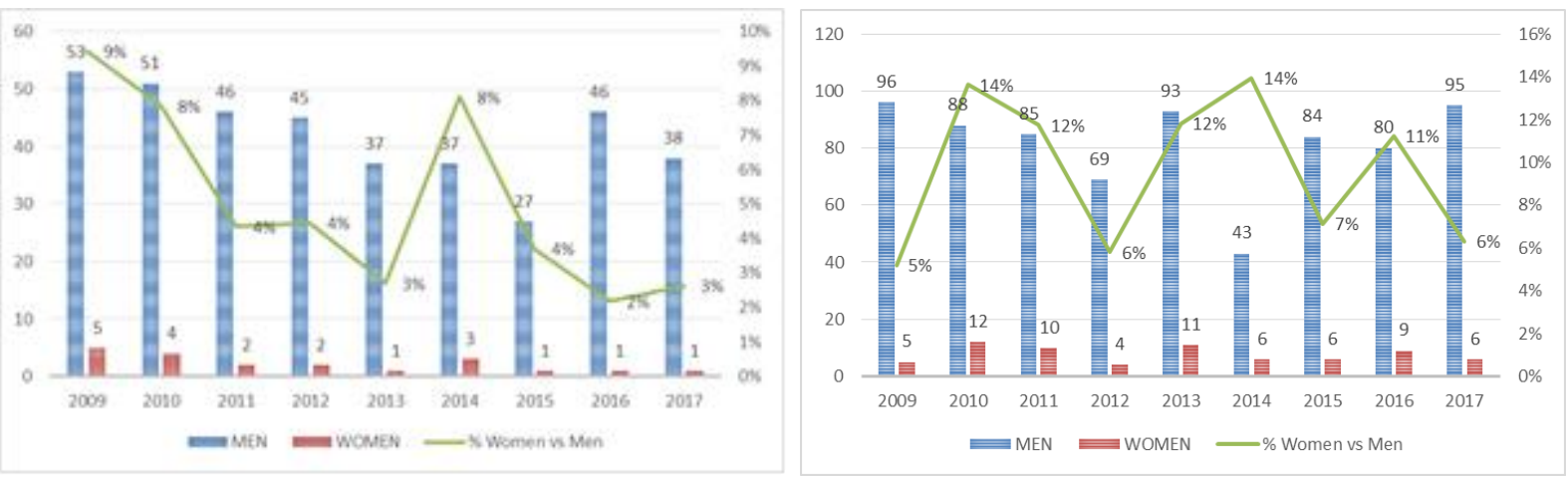

Fig. 12 Chief Engineer CoC Gender Distribution

Fig. 13 OOW Engine Room CoC Gender Distribution

In the graphs above (Fig. 10,11, 12 and 13), it can be observed how the percentage of women is higher for deck positions both at operational and management level, which repeats the pattern of academic degrees described in the previous section. Out of 3,295 Certificates of Competency $(\mathrm{CoC})$ issued by the Spanish Maritime Administration in the period studied, 382 correspond to women, which represents a 13\%. According to the different specializations and rank, a 15\% (83) of the Master and a 24\% (210) of the Officer Of the Watch (OOW) Navigation CoCs correspond to women. As for female Chief engineers the percentage drops to 5\% (20) whereas for female OOW Engine Room engineers the percentage is $9 \%$ (69). The graphs also show a downward trend with respect to women becoming Chief Engineers and Second Deck Officers though less markedly in the second case. The average of women obtaining OOW Engine Room CoCs remains quite steady throughout the period examined. Finally, the numbers of women becoming Captains also have a similar behaviour to that of Chief Engineers, except for a slight upturn in the last two years.

It can be observed how the percentage of women is higher for deck positions both at operational and management level, which repeats the pattern of academic degrees described in the previous section. The graphs also show a downward trend with respect to women becoming Chief Engineers and Second Deck Officers though less markedly in the second case. The average of women becoming Engineer Officers remains quite steady throughout the period examined. Finally, the numbers of women becoming Captains also have a similar behaviour to that of Chief Engineers, except for a slight upturn in the last two years.

The data analysed illustrate that there seems to be a similar percentage of women abandoning the profession before reaching the Captain position (60\%) and the Chief Engineer position (70\%). With respect to men, these percentages drop to $25 \%$ for those that abandon before becoming Captains and to $49 \%$ for Chief Engineers. In light of this, it can be concluded that there are not only fewer women working at sea than men but also that more women than men abandon their careers at sea before earning their positions as Captains and Chief Engineers. 


\section{CONCLUSIONS}

The findings and observations of this small-scale study illustrate how the gender gap in maritime education and training continues in all the institutions analysed over the last decade. Female student figures have the lowest percentages in all studies and in the case of Marine Engineering degrees girls seem to abandon their training more frequently than boys. Nautical Science and Maritime Transport studies are, in general, the ones with higher percentages of female students and also the ones with a lower dropout rate. All the same, it is important to point out that, concerning the mean value of female students enrolled and graduated in Maritime studies in some European MET universities between 2009 and 2018, there is no significant raising tendency for any of the studies examined. It is unclear, however, to what extent these results reflect an actual current trend as a wider sample of MET institutions would have to be surveyed. In addition, as stated in section 4.2. above, the limitations of this study did not consider other additional factors, other than female student promotion policies, that may have had an influence on the results and so explain the changing tendency obtained.

In the professional sector in Spain the situation repeats itself, namely, the percentages of women obtaining their CoCs is higher in the Navigation area and lower for Marine Engineering. However, this situation worsens as women often, and more frequently than men, abandon their careers before reaching high positions. As some studies point out, this is due to different reasons but it is frequently connected to a change in their expectations (Ibañez et al. 2013). In addition, here again, trends seem to persist as there isn't any significant or steady upsurge concerning the recruitment figures in any of the instances examined over time. In order not to reproduce this gender bias and favour women retention in the professional maritime sector, companies should try to adopt conciliation policies to balance professional and family life to the benefit of gender equality (Brickman 2018).

In spite of an increasing awareness and some isolated efforts to reverse this gender gap situation (Kitada et al. 2015; Horck 2010), female student policies are still scarce or non-existent in most institutions. Gender issues seem to be entirely dependent on institutional leaders who are favourable to set guidelines for more inclusive gender-policies. This awareness and willingness to change policies is welcome but it is not enough. If there isn't a perception of having a real problem, possible solutions won't be addressed and there is an urgent need for a new push to overcome gender imbalance and guarantee the success of gender equity. Therefore, a more in depth analysis and a wider applicability of such policies is required, even across countries, as most of the times they work only at national or institutional level. There have already been some attempts at implementing international programmes to promote gender equality and women advancement, for example by the UN and the IMO among others (Romero 2017). In line with this, the joint involvement of national maritime administrations and international maritime organisations and agencies in the development of gender equity policies might be an important and more effective step towards developing a more egalitarian and inclusive maritime education and training system.

Furthermore, this study does not include considerations of gender discourse or pedagogy in the institutions analysed as it is not within the scope of the present study, but this is also something that would demand attention if we are willing to resolve the present gender gap situation (Boström and Österman 2015). Increasing the numbers of female students is not enough if it does not go hand in hand with changes in the pedagogy and the curricula of MET institutions as the weight of the male-dominated cultural and historical maritime context will be otherwise difficult to overcome.

Finally, this paper also raises a broader question: When should promotion of maritime studies begin among prospective female students? Beginning promotion at university level might be too late, as female students may have already anticipated more humanistic degrees. Thus, starting promotion in secondary, and even primary, education could be a more successful attempt to obtain better results to leave behind the present gender inequality in maritime studies. This is closely related to students' expectations for choosing maritime studies (Pallis and NG 2011; Ku et al. 2017). If we try to better understand female students' expectations and motivations for choosing these studies, we will be able to design better promotion policies and strategies and we can even try to implement them at earlier educational stages.

\section{REFERENCES}

Boström Cars M and Österman C (2015) Mind the gap! Maritime Education for gender-equal career advancement. In: Maritime Women: Global Leadership: 143-154. Berlin, Heidelberg. https://doi.org/10.1007/978-3-662-45385-8_11 
Brickman JP (2014) Recruitment and Retention of Women in the Maritime Industry. In: The 13th Annual General Assembly of the IAMU, Expanding Frontiers - Challenges and Opportunities in Maritime Education and Training. http://iamu-edu.org/wp-content/uploads/2014/07/Recruitment-and-Retention-ofWomen-in-the-Maritime-Industry.pdf. Accessed 16 June 2018

Cars MB, Österman C (2015) Mind the Gap! Maritime Education for Gender-Equal Career Advancement. In: Kitada M., Williams E., Froholdt L. (eds) Maritime Women: Global Leadership. WMU Studies in Maritime Affairs, vol 3. Springer, Berlin, Heidelberg

De la Campa R, Bouza MA, Estopá H and Alcolea RM (2013) The role of Spanish women in the merchant marine in XXI century. In: 2013 International Conference Proudly Empowering Women in Maritime: Barcelona, Spain: 29-50. ISBN 9788476539996

Dragomir C et al. (2018) Final Report IAMU 2017 Research Project No. 20170305 Gender Equality and Cultural Awareness in Maritime Education and Training (GECAMET), IAMU, Tokyo, ISBN 978-4907408-23-7

European Commission (2018) European Commission/EACEA/Eurydice: The European Higher Education Area in 2018: Bologna Process Implementation Report. Luxembourg: Publications Office of the European Union.

European Commission (2019) Horizon 2020 Research and Innovation programme. https://ec.europa.eu/programmes/horizon2020/en/what-horizon-2020. Accessed 14 May 2019

Horck J (2010) The gender perspective in maritime education and training. WMU J Marit Affairs 9: 93. https://doi.org/10.1007/BF03195168

Ibañez I, Díaz E and Fernández-Martínez LM (2013) Changing expectations and beliefs: three decades of women seafarers in Spain. In: 2013 International Conference Proudly Empowering Women in Maritime: Barcelona, Spain, 73-95. ISBN 9788476539996.

International Maritime Organization (1989) Strategy on the Integration of Women in the Maritime Sector (IWMS). IMO'S Women in Development Programme.

International Maritime Organization (1988) IMO's gender programme. http://www.imo.org/en/OurWork/TechnicalCooperation/Pages/WomenInMaritime.aspx. Accessed 9 May 2019

International Transport Forum, ITF (2019) ITF Work on gender in transport. https://www.itf-oecd.org/gendertransport. Accessed 10 May 2019

Joy L, Wagner HM, Narayanan S (2007) The Bottom Line: Corporate Performance and Women's Representation on Boards. https://www.catalyst.org/research/the-bottom-line-corporate-performanceand-womens-representation-on-boards/ Accessed 6 May 2019

Kitada M, Williams E and Froholdt LL (2015) Maritime Women: Global Leadership. WMU Studies in Maritime Affairs, Springer. ISBN 978-3-662-45385-8. https://doi.org/10.1007/978-3-662-45385-8

$\mathrm{Ku}$ K-N et al (2017) Factors Affecting Female Students' choice of Maritime Majors. Journal of Marine Science and Technology, 25(4), 417-423. DOI: 10.61. 9/JMST-017-0322-1

Martínez de Osés FX (2002) Situación de la mujer ante los estudios marítimos y la marina Mercante. Barcelona: UPC.https://upcommons.upc.edu/bitstream/handle/2117/561/La\%20mujer\%20en\%20la\%20Marina\%20 Mercante.pdf. Accessed 17 June 2018 (in Spanish)

Official State Gazzette (BOE) Organic Law 3/2007, of March 22, for effective gender equality (in Spanish)

Official Journal of the Catalan Government (DOGC) 6919, 23/07/2015 Law 17/2015 of 21 July, on effective equality between women and men (in Catalan)

Pallis AA and NG AKY (2011) Pursuing maritime education: an empirical study of students' profiles, motivations and expectations. MARIT. POL. MGMT. 38(4): 369-393

Romero Lares MC (2017) A Case Study on Gender Equality and Women's Empowerment Policies Developed by the World Maritime University for the Maritime Transport Sector. TransNav, the International Journal on Marine Navigation and Safety of Sea Transportation. Faculty of Navigation, Gdynia Maritime University, 11(4): 583-587. ISNN 2083-6481

Romero Lares MC and Kitada M (2013) An overview of the United Nations millennium development goal on gender equality and empower of women (in the maritime sector). In: 2013 International Conference Proudly Empowering Women in Maritime: Barcelona, Spain: 18-28. ISBN 9788476539996.

Romero Lares MC and Kitada M (2014) Maritime Women: Global Leadership: Book of Abstracts. Malmö.

Ship Technology (2018) Industry views: addressing gender inequality in the maritime sector. https://www.shiptechnology.com/features/industry-views-addressing-gender-inequality-maritime-sector/. Accessed 26 April 2019 
Universitat Politècnica de Catalunya, BarcelonaTech (2007). I Pla Director d'Igualtat d'Oportunitats 2007-2010. Annex I - Evolució demogràfica de gènere. Barcelona (in Catalan)

Universitat Politècnica de Catalunya, BarcelonaTech (2013). II Pla d'Igualtat de Gènere de la UPC, 2013-2015. Barcelona (in Catalan)

Universitat Politècnica de Catalunya, BarcelonaTech (2016). III Pla d'Igualtat de Gènere de la UPC, 2016-2020. Barcelona (in Catalan)

Walker C, Gleaves A and Peart D (2003) Problems in the Construction of Gender and Professional Identities for Women in a United Kingdom Merchant Navy Training School. Research in Post-Compulsory Education. Taylor \& Francis, 8(3), 285-304. ISSN: 1359-6748

YaleGlobal Online (2003) Tough Struggle at sea. https://yaleglobal.yale.edu/content/tough-struggle-sea. Accessed 17 June 2018 


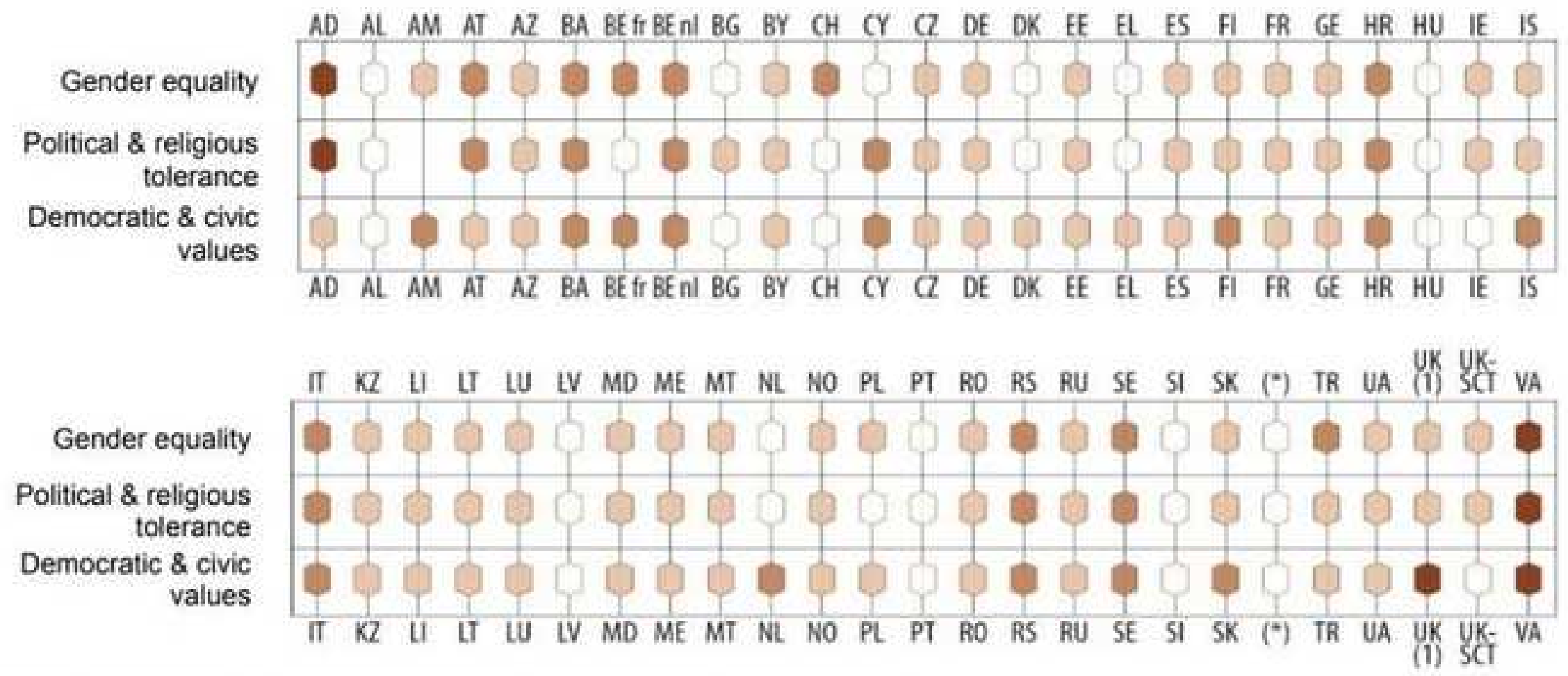

(*): the former Yugoslav Republic of Macedonia; UK (1); UK-ENG/WLS/NIR 


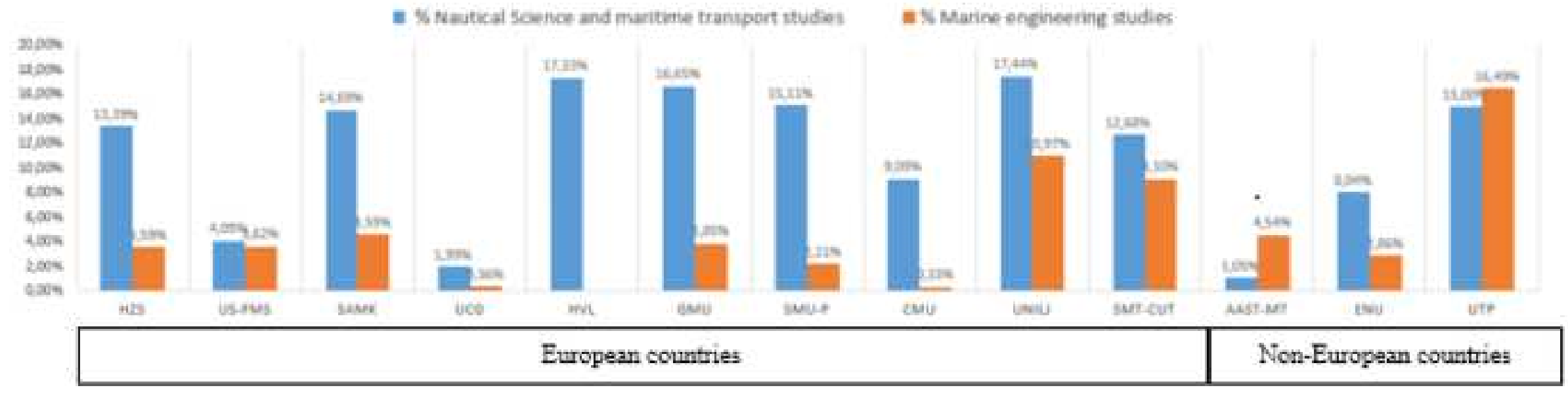




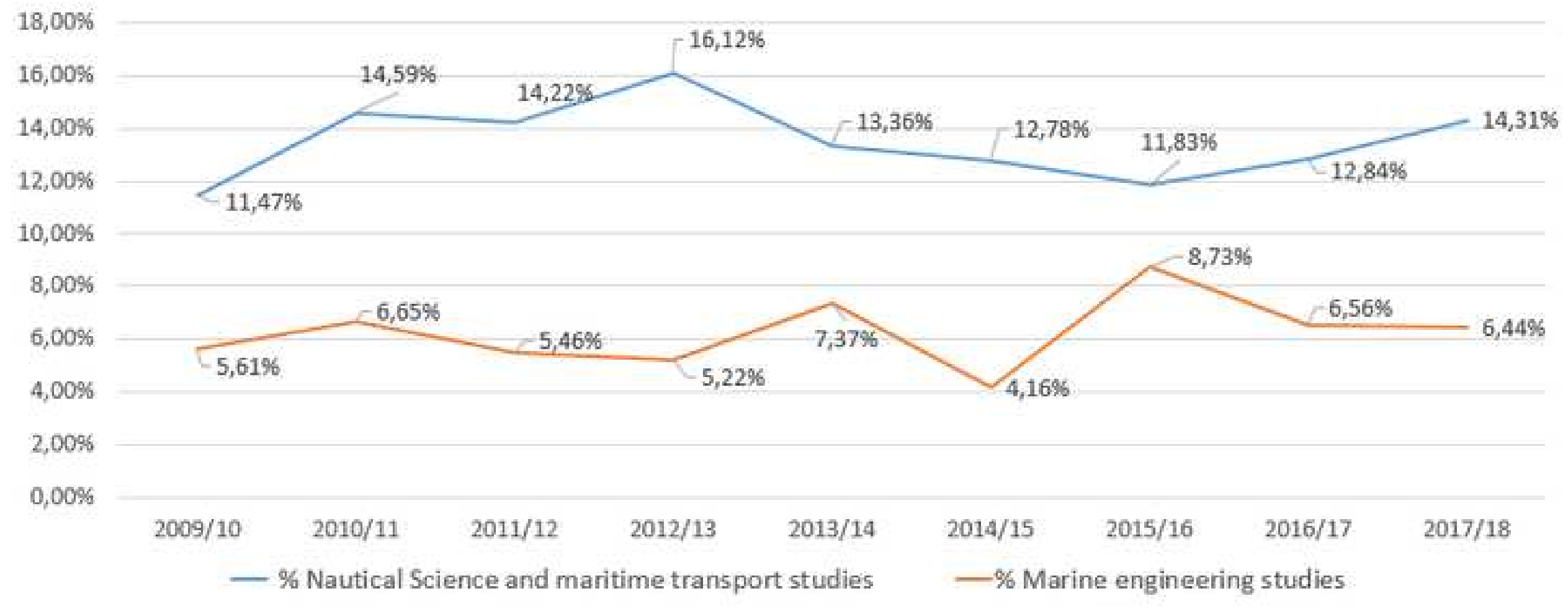




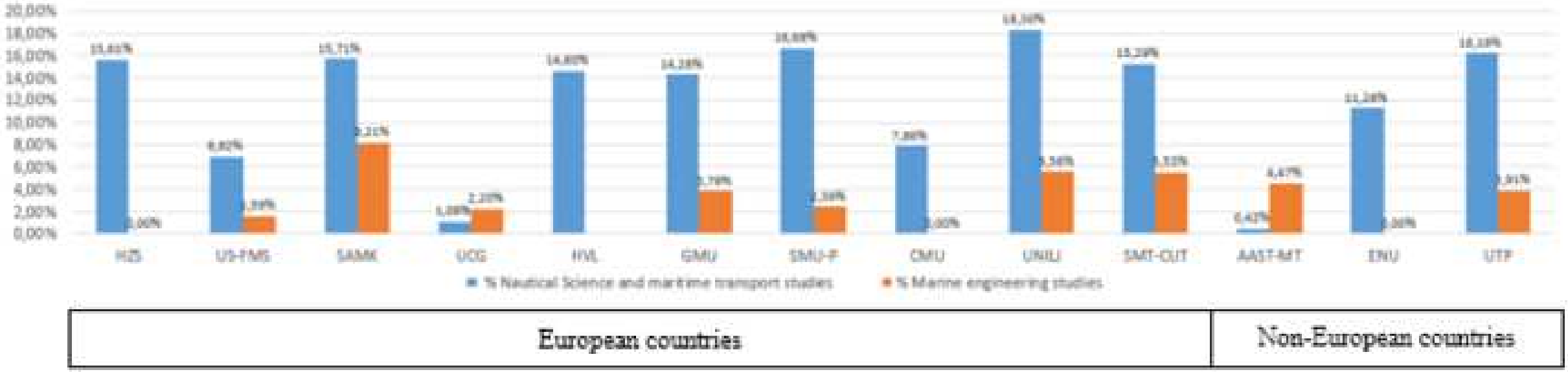


$25,00 \%$

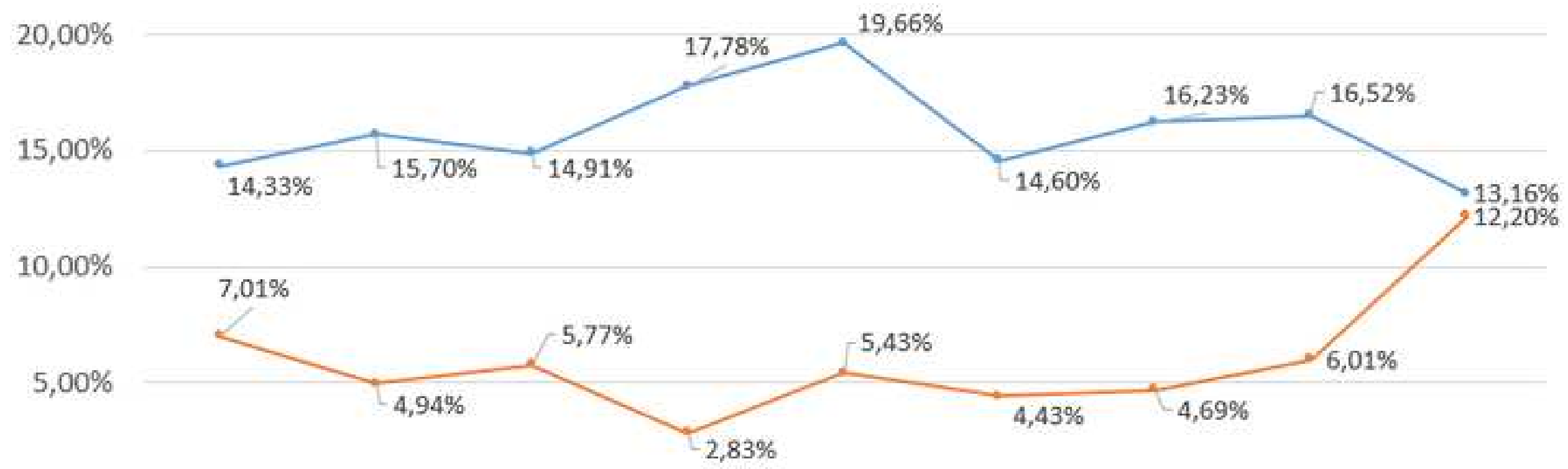

$0,00 \%$

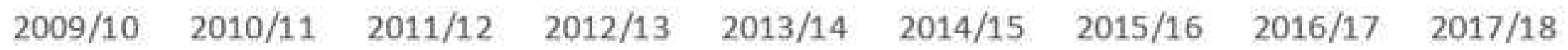

$\rightarrow \%$ Nautical Science and maritime transport studies $\quad \rightarrow \%$ Marine engineering studies 


$$
25,00 \%
$$

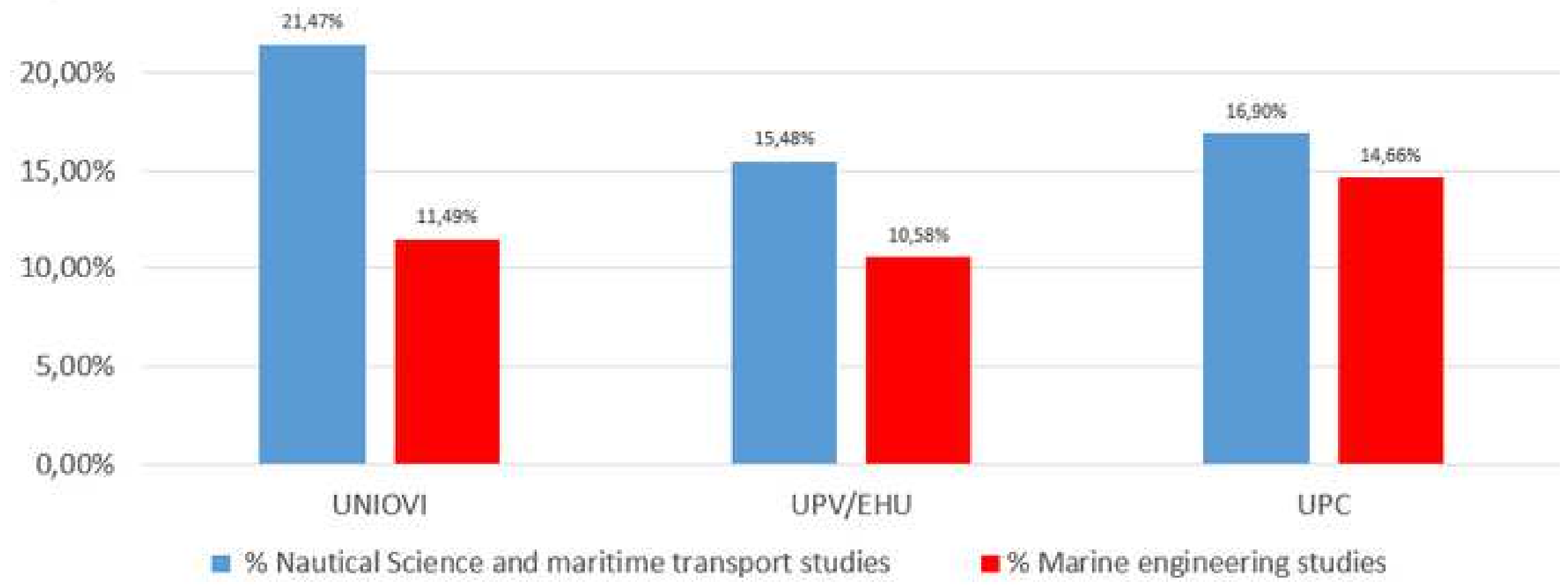


$30,00 \%$

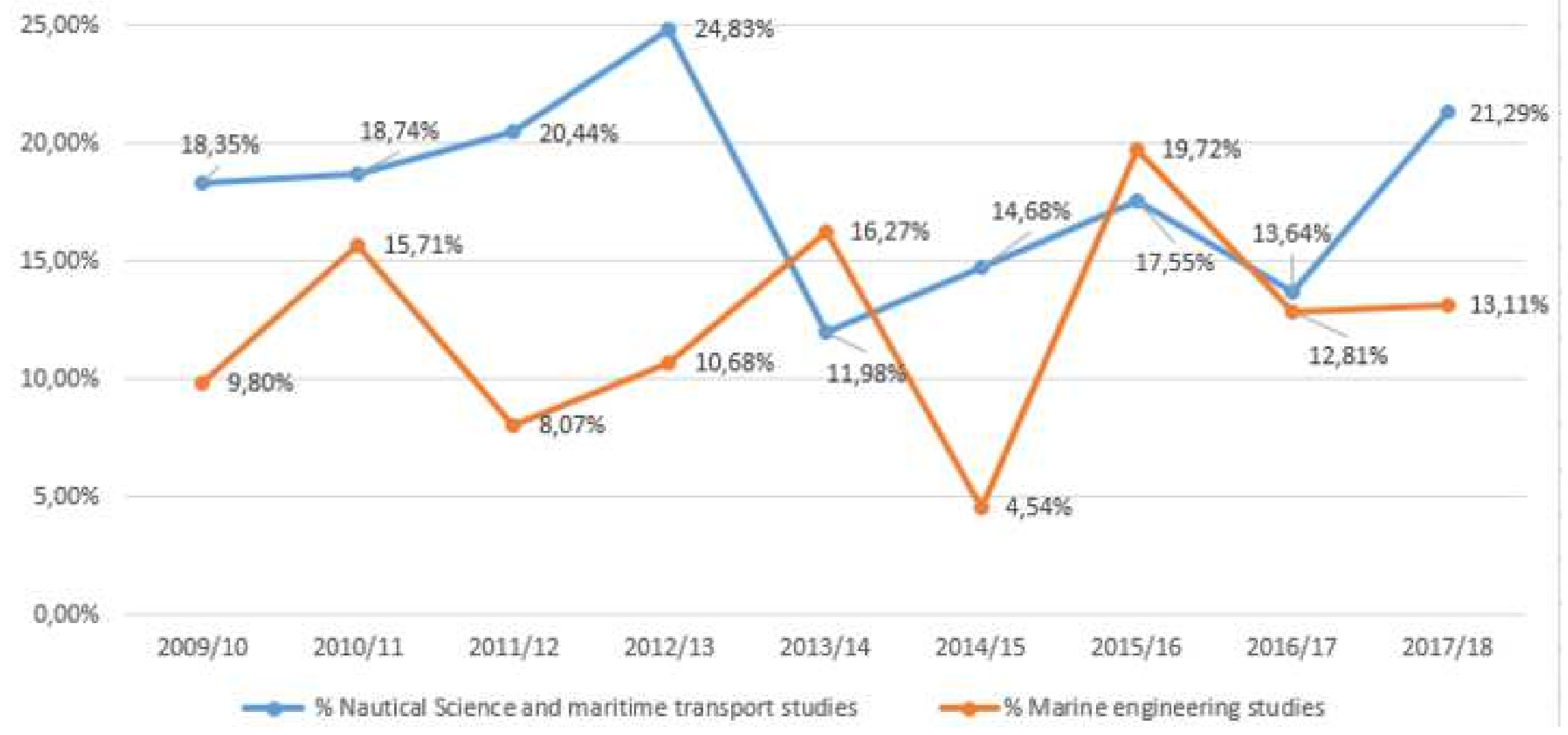


$40,00 \%$

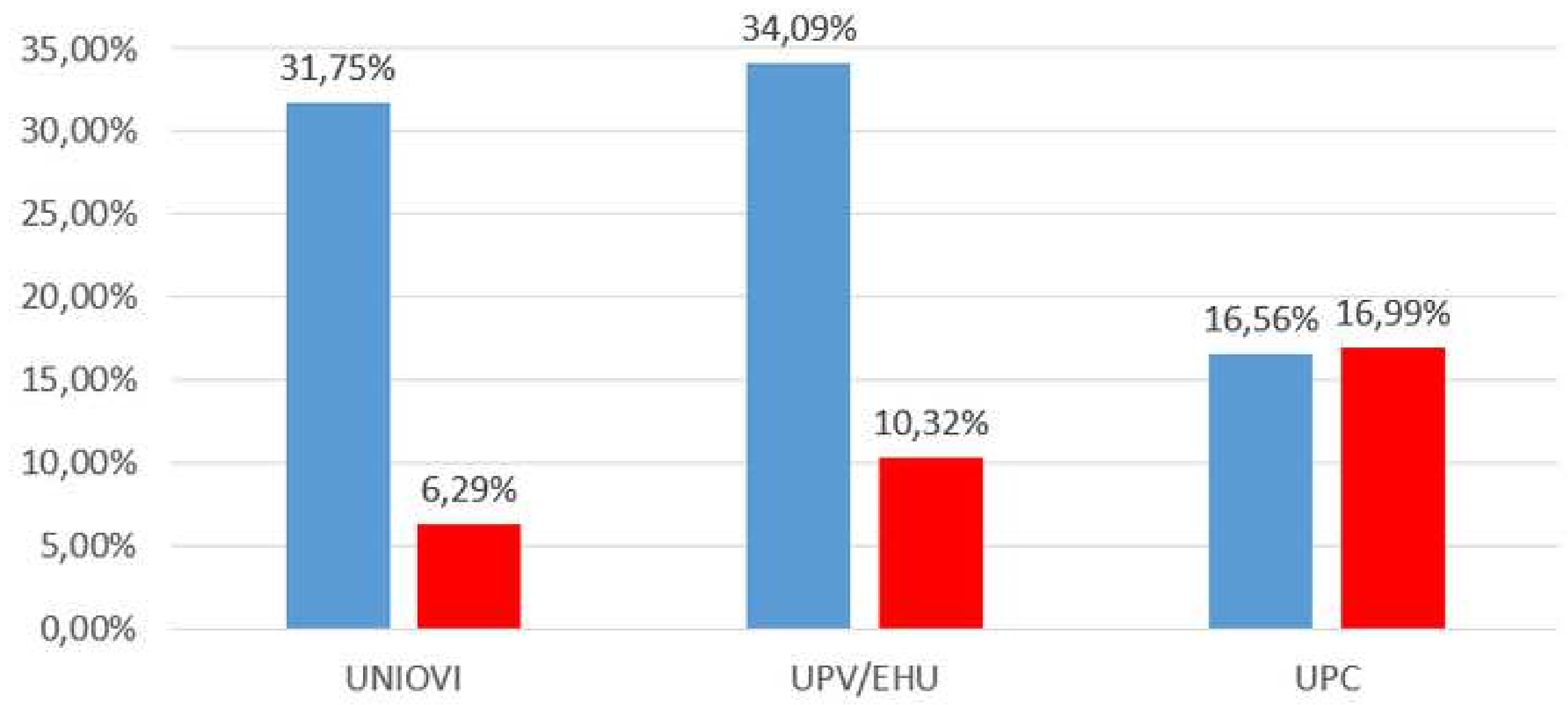

\% Nautical Science and maritime transport studies a Marine engineering studies 
$45,00 \%$ $40,00 \%$ $35,00 \%$ $30,00 \%$ $25,00 \%$ $20,00 \%$ $15,00 \%$ $10,00 \%$ $5,00 \%$

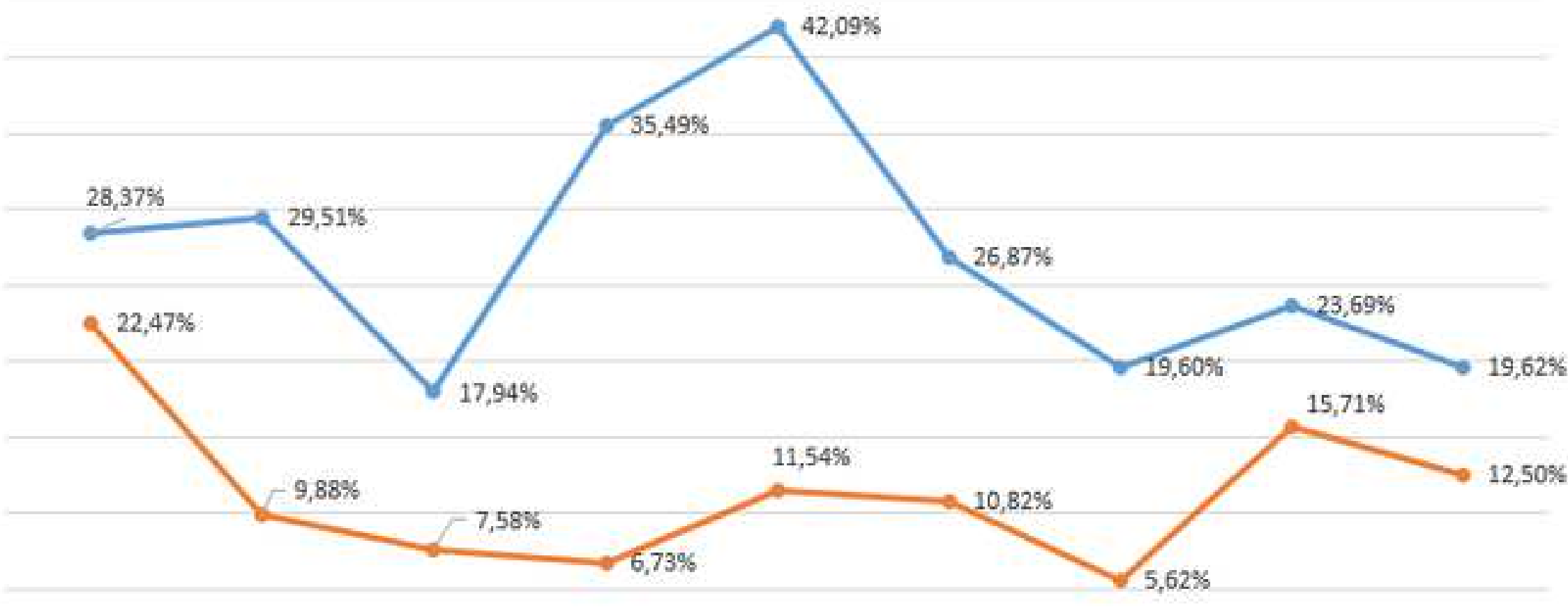
$0,00 \%$ 2009/10 2010/11 2011/12 2012/13 2013/14 2014/15 2015/16 2016/17 $\quad 2017 / 18$ $\approx \%$ Nautical Science and maritime transport studies $\quad \approx \%$ Marine engineering studies 


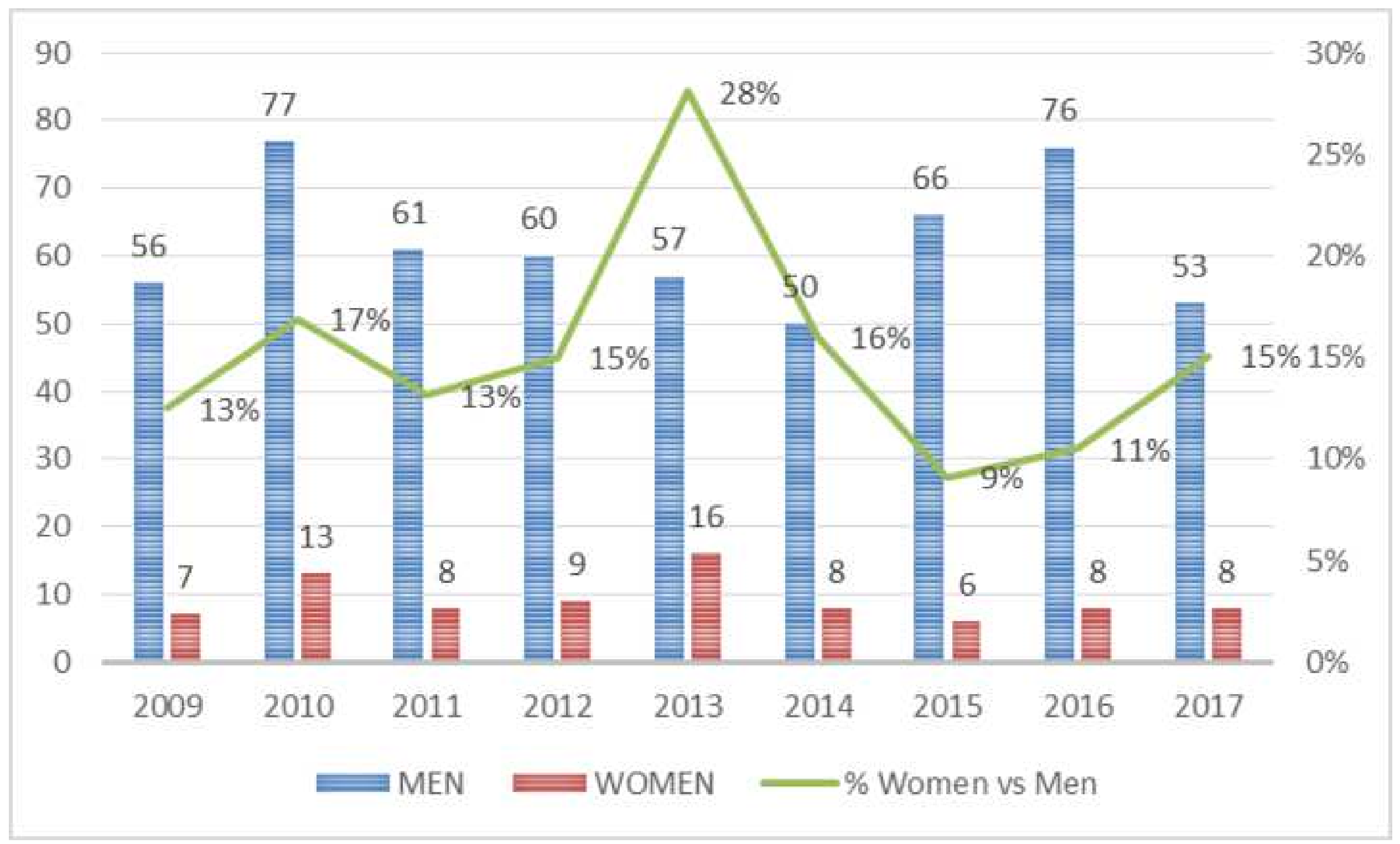




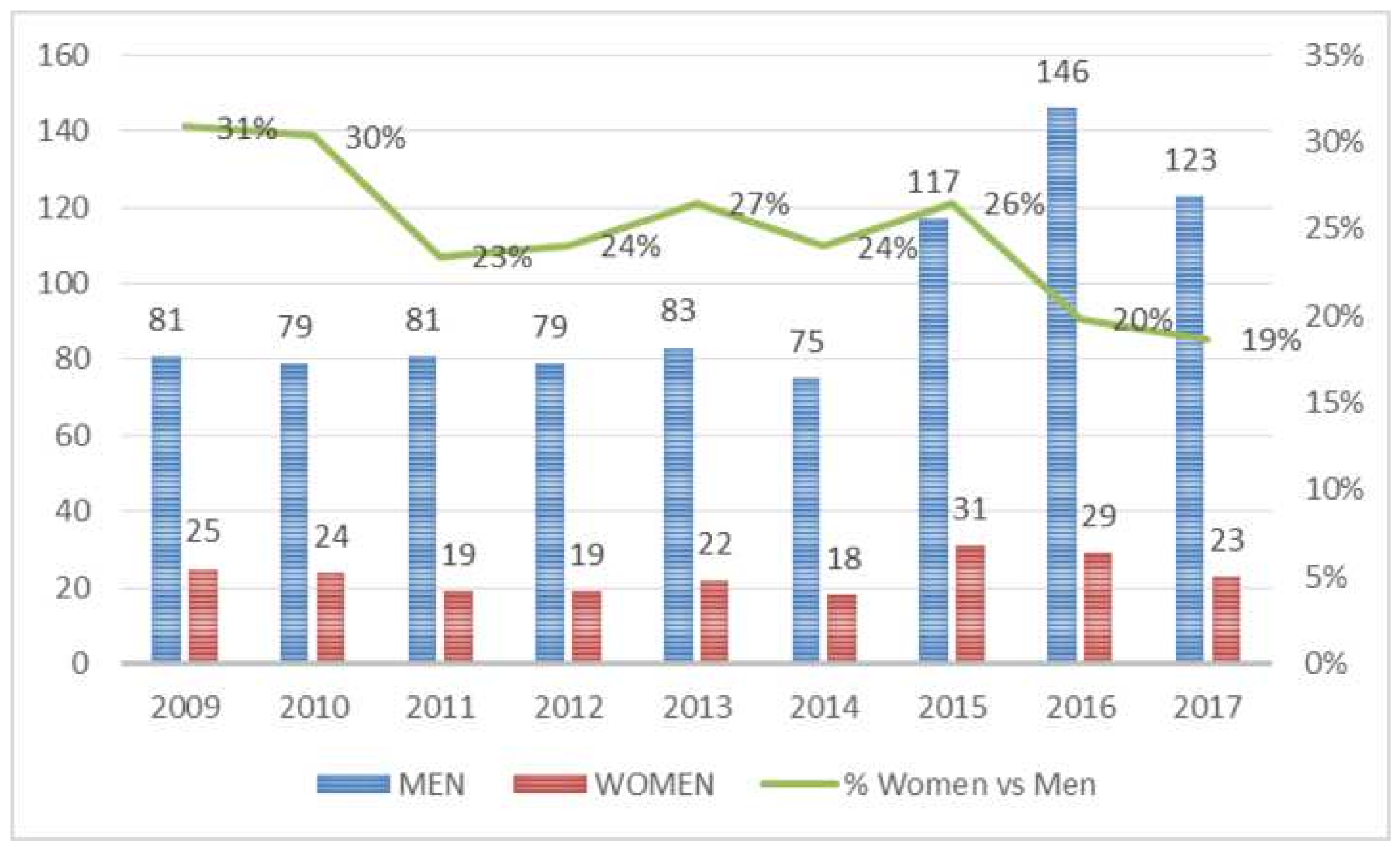




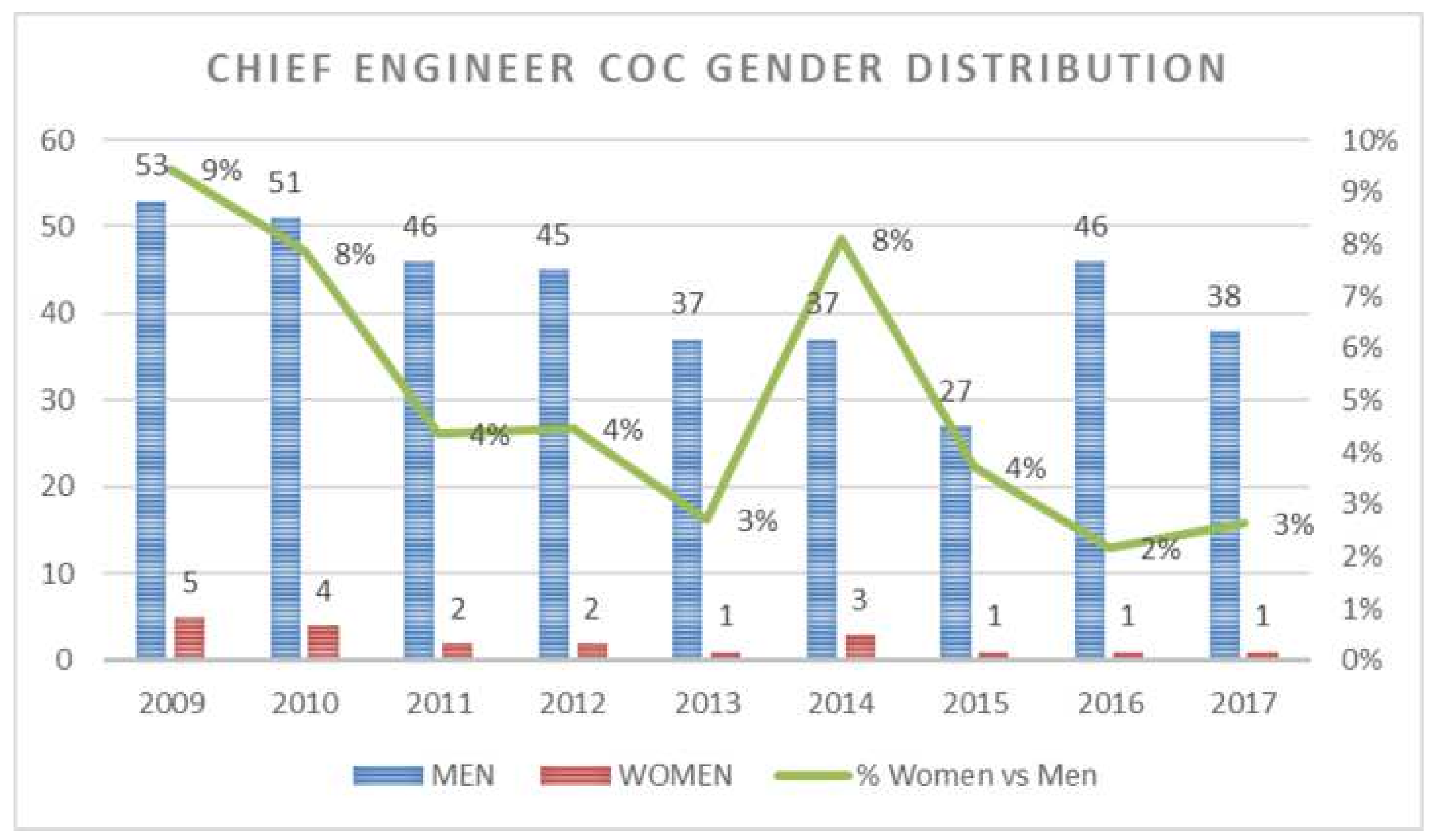

\section{CHIEF ENGINEER COC GENDER DISTRIBUTION}




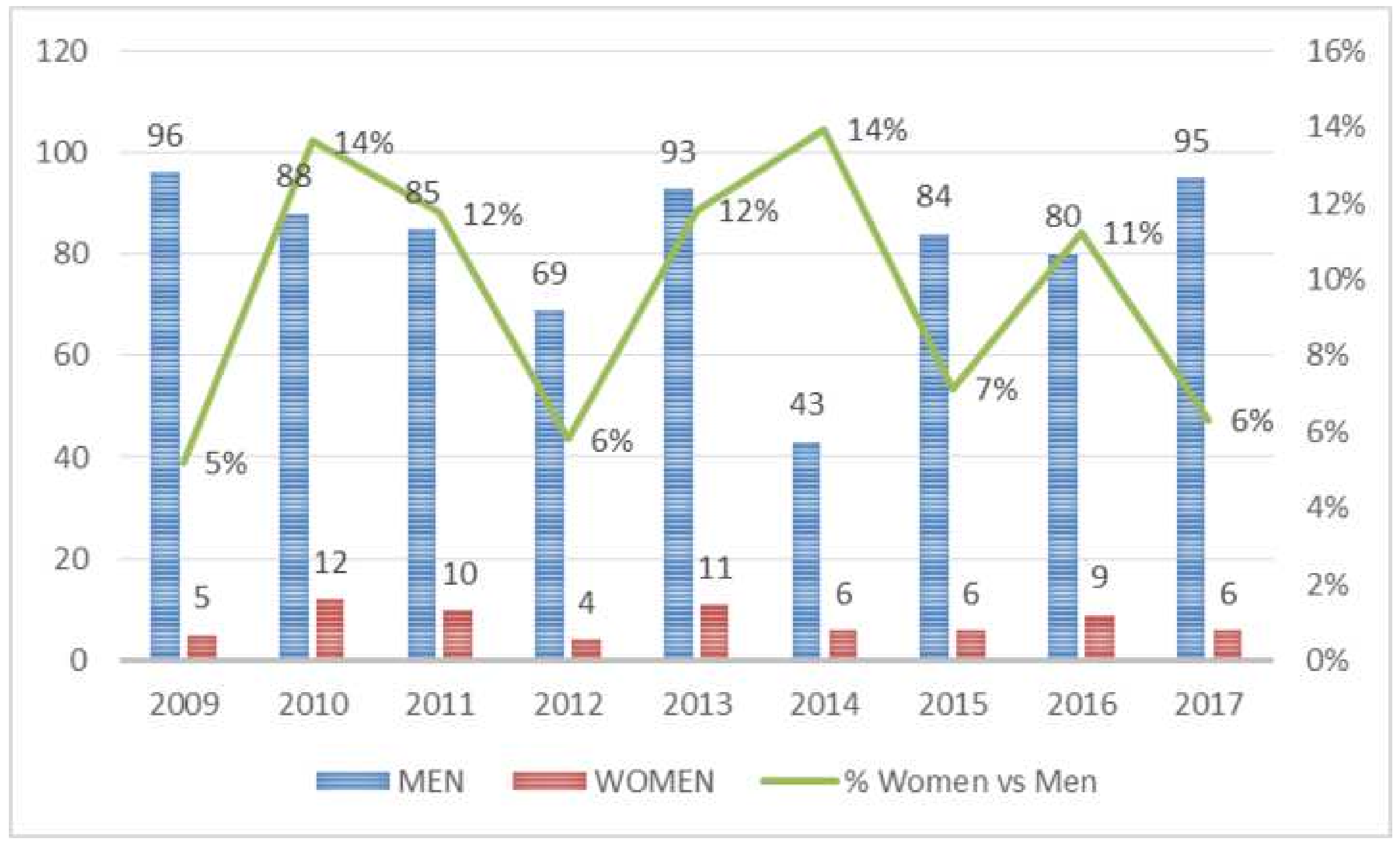

$6 \% \quad 6 \%$

$4 \%$

20

0

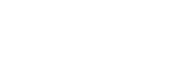




\begin{tabular}{|l|l|l|}
\hline Country & Institution & Identifying acronym \\
\hline European countries & HZS \\
\hline Belgium & Antwerp Maritime Academy & US_FMS \\
\hline Croatia & University of Split, Faculty of Maritime Studies* & SAMK \\
\hline Finland & Satakunta University of Applied Sciences* & UCG \\
\hline $\begin{array}{l}\text { Montene } \\
\text { gro }\end{array}$ & University of Montenegro & HVL \\
\hline Norway & Western Norway University of Applied Sciences* & GMU \\
\hline Poland & Gdynia Maritime University* & SMU-P \\
\hline Poland & Szczecin Maritime University* & CMU \\
\hline Romania & Constanta Maritime University* & UNILJ \\
\hline Slovenia & University of Ljubljana & SMT-CUT \\
\hline Sweden & Chalmers University of Technology* & UNIOVI \\
\hline \multicolumn{2}{|l}{} & UPV/EHU \\
\hline Spain & Universidad de Oviedo, Escuela Superior de la Marina Civil & UPC-FNB \\
\hline Spain & Universidad del País Vasco, Escuela de Ingeniería de Bilbao & \multicolumn{2}{|l}{} \\
\hline Spain & Universitat Politècnica de Catalunya, Facultat de Nàutica de Barcelona* & AAST-MT \\
\hline Non-European countries & UTP \\
\hline Egypt & Arab Academy for Science, Technology and Maritime Transport* & ENU \\
\hline Perú & Universidad Tecnológica de Perú* & \\
\hline Uruguay & Escuela Naval de Uruguay & \\
\hline
\end{tabular}

